\title{
PERANCANGAN KLAIM UNTUK HUMAN RESOURCE DEVELOPMENT SYSTEM PADA PT PROTONEMA BERBASIS ANDROID
}

\author{
Ayu Delima ${ }^{1}$, Rudi Hermawan ${ }^{2}$, Harmi Ibnu Djafar ${ }^{3}$ \\ Program Studi Informatika, Fakultas Teknik dan Ilmu Komputer, Universitas Indraprasta PGRI \\ Jalan Raya Tengah No 80, Kelurahan Gedong, Pasar Rebo, Jakarta Timur \\ Ayudelima18@gmail.com ${ }^{1}$, Rh001unindra@gmail.com², Djafar2662@gmail.com³
}

\begin{abstract}
Abstrak
Teknologi informasi merupakan salah satu teknologi yang diterapkan di beberapa perusahaan. Hal ini membuat teknologi informasi banyak dipergunakan untuk kecepatan proses data dan keakuratan dalam proses laporan yang diperlukan. Teknologi informasi komputer banyak digunakan dalam dunia usaha maupun dalam dunia pendidikan. Salah satu yang memanfaatkan kecanggihan teknologi informasi komputer adalah PT Protonema. PT Protonema merupakan perusahaan yang bergerak di bidang teknologi yang berdiri pada bulan Juli 2013 sampai saat ini masih terus beroperasi. Dengan banyaknya karyawan yang bekerja, pihak PT Protonema sangat kesulitan dan memerlukan waktu yang cukup lama untuk memproses pengolahan data setiap karyawan. Seperti data klaim kesehatan, klaim lembur, dan detail data lainnya. Semua proses tersebut masih dilakukan secara manual dan prosesnya memerlukan waktu yang cukup lama. Sehingga laporan keuangan perusahaan terhadap klaim karyawan dan informasi pemberitahuan lainnya sangat lama diterima. Selain itu, diharapkan sistem tersebut dapat mengurangi penggunaan kertas.
\end{abstract}

Kata Kunci : rancangan, klaim, sumber daya manusia, cuti, android

\begin{abstract}
Information technology is one of the technologies implemented in several companies. This makes information technology widely used for data processing speed and accuracy in the process of reports required. Computer information technology is widely used in business and in the world of education. One that utilizes the sophistication of computer information technology is PT Protonema. PT Protonema is a technology company that was established in July 2013 until now continues to operate. With many employees working, PT Protonema is very difficult and takes a long time to process the data processing of each employee. Such as health claim data, overtime claims, and other data details. All these processes are still done manually and the process takes a while. So that the company's financial statements against employee claims and other notification information are very long received. In addition, it is hoped that the system can reduce paper usage.
\end{abstract}

Keywords: draft, claim, human resource, paid leave, android

\section{PENDAHULUAN}

Teknologi informasi merupakan salah satu teknologi yang diterapkan di beberapa perusahaan. Hal yang membuat teknologi informasi banyak dipergunakan adalah kecepatan dalam proses data dan keakuratan dalam proses laporan yang diperlukan. Teknologi informasi yang sering dipergunakan dalam dunia usaha maupun dalam dunia pendidikan adalah teknologi informasi komputer. Dengan melihat kecanggihan teknologi informasi komputer tersebut banyak perusahaan baik perusahaan yang bergerak dibidang jual beli, pendidikan, media, jasa dan yang bergerak di bidang sosial mengubah sebuah sistem manual yang telah berjalan ke dalam sebuah sistem yang mengandalkan kecanggihan teknologi informasi komputer. Salah satu yang ingin memanfaatkan kecanggihan teknologi informasi komputer adalah PT Protonema. PT Protonema merupakan usaha yang bergerak di bidang teknologi yang berdiri pada bulan Juli 2013 hingga saat ini masih terus tetap beroperasi. Dengan melihat banyaknya jumlah karyawan yang bekerja disini, pihak PT Protonema merasa sangat kesulitan dan memerlukan waktu yang cukup lama untuk memproses pengolahan data setiap karyawan/karyawati tersebut seperti data klaim kesehatan, klaim lembur, dan detail data lainnya. semua proses tersebut masih dilakukan secara manual dan setiap proses yang dilakukan memerlukan waktu yang cukup lama. Sehingga laporan keuangan perusahaan terhadap klaim karyawan/karyawati atau informasi 
pemberitahuan lainnya sangat lama didapatkan. Dengan melihat kemajuan teknologi informasi komputer saat ini, maka pihak PT Protonema berkeinginan mengubah suatu sistem manual yang selama ini berjalan untuk menangani proses pengolahan data ke dalam sebuah proses yang mengandalkan teknologi informasi komputer, karena diharapkan dengan adanya sistem yang lebih baik ini seluruh proses yang ada untuk pengolahan data dapat berjalan secara efisien dan efektif, selain itu juga diharapkan sistem tersebut dapat meminimalisir penggunaan kertas. Oleh karena itu dengan melihat keinginan pihak PT Protonema tersebut, maka penulis berkeinginan membuat suatu sistem tersebut dengan judul "Perancangan Klaim untuk Human Resource Development (HRD) System pada PT Protonema Berbasis Android". Sistem yang penulis buat nantinya diharapkan dapat digunakan sesuai keinginan pihak PT Protonema, seperti melakukan proses pengolahan data, diantaranya yaitu untuk klaim kesehatan, klaim lembur, dan detail data lainnya. Diharapkan setiap proses yang ada dapat berjalan secara efektif dan efisien, serta meminimalisir kesalahan dan penggunaan kertas. Kegunaan penelitian ini bermanfaat bagi peneliti yaitu menambah pengetahuan dan wawasan tentang perancangan sistem informasi klaim.

\section{PENELITIAN RELEVAN}

Penelitian relevan dari (Ahmad Cucus, 2015, 2087-2062). Perancangan Sistem Informasi Klaim Asuransi Jiwa Pada PT. Asuransi Jiwasraya Kota Bandar Lampung. Sistem informasi adalah suatu sistem didalam suatu organisasi yang mempertemukan kebutuhan pengelohan transaksi harian, pendukung operasi, bersifat manajerial, dan kegiatan strategi dari suatu organisasi dan menyediakan kepada pihak luar tertentu dengan laporan-laporan yang diperlukan. Adapun pelayanan yang diberikan oleh perusahaan tersebut berupa jasa asuransi jiwa yaitu dengan memberikan proteksi kepada nasabah dengan pelayanan prima dan selalu bertekat untuk senantiasa menepati janji, sesuai dengan apa yang dijajikan, namun dalam pengurusanya pada bagian klaim masih menggunakan waktu yang cukup lama baik dalam pencarian data nasabah, serta dalam pembuatan laporan klaim. Sehingga waktu yang ada tidak dapat dipergunakan dengan semaksimal mungkin dalam pemerosesan data klaim nasabah pada PT. Asuransi Jiwasraya. Menanggapi permasalahan yang ada itulah, maka peneliti ingin membantu merancang sebuah sistem informasi klaim Asuransi jiwa dengan judul: "Perancangan Sistem Informasi Klaim Asuransi Jiwa dengan menggunakan pemrograman Ms. Visual Basic 6.0 pada PT. Asuransi Jiwasraya Kota Bandar Lampung". (Cucus, 2015).

Penelitian relevan dari (Dwi Prasetyo Utomo, Andrei Ramani, Yunus Ariyanto. 2015, 2355-7036). Perancangan Sistem Informasi Klaim Persalinan Studi Kasus di Badan Penyelenggara Jaminan Sosial Kesehatan Kantor Cabang Jember. Layanan kebidanan dan neonatal Badan Penyelenggara Jaminan Sosial Kesehatan (BPJS Kesehatan) adalah upaya untuk memastikan dan melindungi proses kehamilan, persalinan, pascapersalinan, perawatan perdarahan pascakelahiran keguguran, dan layanan kontrasepsi setelah melahirkan di fasilitas kesehatan tingkat pertama. Biaya perawatan kebidanan dan neonatal di fasilitas kesehatan tingkat pertama dapat diklaim di BPJS Kesehatan, tetapi pada implementasi pengajuan klaim pengiriman yang dilakukan oleh fasilitas kesehatan tingkat pertama ke BPJS Kesehatan menunda pengajuan klaim dan banyak file tidak lengkap. Tujuan penelitian adalah membuat model sistem informasi klaim pengiriman. Penelitian ini menggunakan metode penelitian dan pengembangan, prototipe digunakan untuk perancangan sistem informasi yang tahapannya terdiri dari pengumpulan data untuk menentukan kebutuhan akan data dan informasi melalui wawancara mendalam dengan bidan, puskesmas Sumbersari, Dinas Kesehatan Kabupaten Jember, dan BPJS Kesehatan Kantor Cabang Jember, kemudian dilanjutkan dengan perancangan sistem informasi dan tahap validasi sistem informasi klaim pengiriman. Output yang dihasilkan adalah diagram alir, diagram konteks, diagram alir data, dan diagram hubungan entitas dari sistem informasi klaim pengiriman.(Utomo dkk, 2015) 


\section{METODE PENELITIAN}

Metode penelitian adalah salah satu teknik atau cara mencari data, memperoleh, mengumpulkan atau mencantumkan data yang tepat digunakan untuk keperluan dan faktor-faktor yang berhubungan dengan pokok pembahasan sehingga akan dapat suatu kebenaran atas data yang diperoleh. Peneliti menggunakan metode penelitian dari: Metode penelitian menurut (Cucus, 2015) adalah "Penyaluran rasa ingin tahu manusia terhadap sesuatu masalah dengan perakuan tertentu (seperti memaksa, menghasut, menelaah dan mempelajari secara cermat serta sungguh-sungguh)", sehingga diperoleh sesuatu (seperti mencapai kebenaran, dan sebagainya)". Sedangkan penelitian menurut (Kusumah, 2014) "Metode penelitian merupakan cara ilmiah untuk mendapatkan data dengan tujuan dan kegunaan tertentu". Dari beberapa definisi diatas maka dapat disimpulkan bahwa metode penelitian adalah metode yang digunakan untuk mengetahui hasil dari penelitian dengan cara mengumpulkan, mencatat, dan menganalisis informasi data yang ada. Dengan ini Model Prototyping menjadi pilihan yang digunakan dalam pengembangan: Model Prototyping (Metode Prototype) merupakan satu metode dalam pengembangan perangkat lunak, metode ini merupakan suatu paradigma baru dalam pembuatan atau pengembangan perangkat lunak. Metode ini adalah evolusi dalam dunia pengembangan atau pembuatan perangkat lunak, metode ini juga merevolusi metode pengembangan atau pembuatan perangkat lunak yang lama, yaitu sistem sekuensial yang biasa dikenal dengan nama Metode Waterfall. Dalam metode prototype/prototyping, perangkat lunak yang dihasilkan kemudian dipresentikan kepada klien, dan klien tersebut diberikan kesempatan untuk memberikan masukan dan kritikan, sehingga software yang dihasilkan sesuai dengan kebutuhan dan keinginan pelanggan. Perubahan perangkat lunak dapat dilakukan berkali-kali hingga dicapai kesepakatan bentuk dari software yang akan dikembangkan. Metode Pengumpulan Data dilalui dengan proses, studi lapangan yaitu proses surver, observasi dan wawancara. Serta pengembangan system yang melalui proses protoyping dari step awal pengumpulan kebutuhan, membangun prototyping, evaluasi, mengkodean sistem, menguji sistem, evaluasi dan penggunaan sistem.

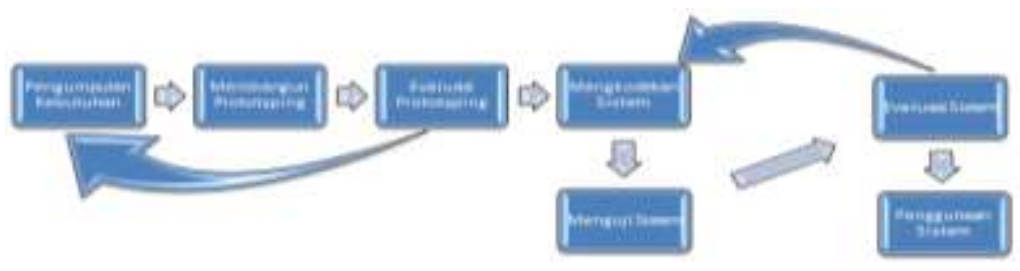

Gambar 1. Tahapan - tahapan prototyping

\section{HASIL DAN PEMBAHASAN}

Struktur navigasi berfungsi untuk menggambarkan dengan jelas hubungan dan rantai kerja seluruh elemen yang akan digunakan dalam aplikasi. Dengan menggambarkan struktur navigasi, pembuatan aplikasi dapat tersusun dengan sistematis dan mudah. Struktur navigasi yang digunakan untuk membuat rancangan sistem klaim ini yaitu navigasi campuran. Yang menghasilkan alur flowchart seperti dibawah ini: 


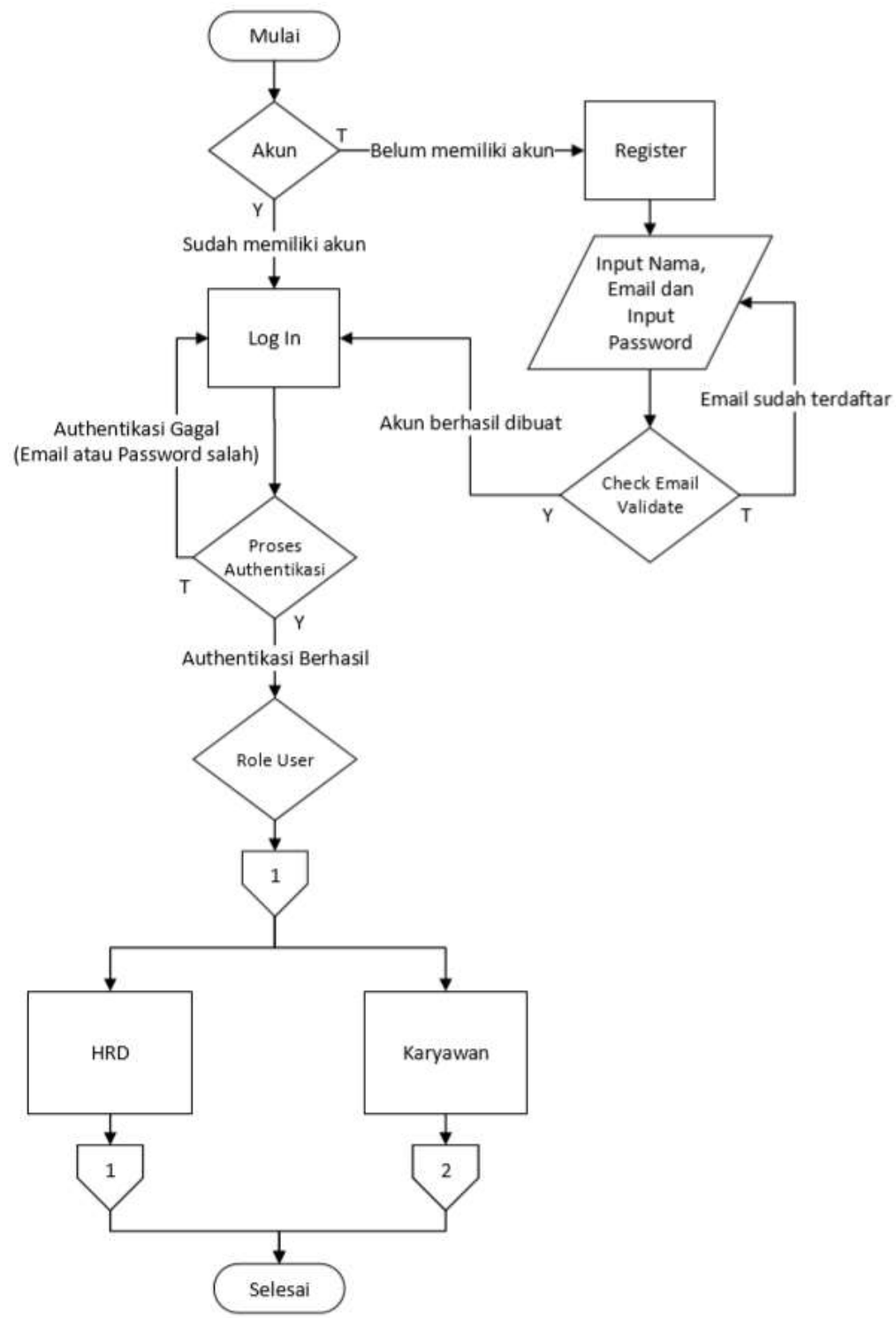

Gambar 2. Flowchart Log In \& Register

Pada rancangan aplikasi ini dapat digunakan untuk 2 user berbeda dan memiliki role dan hak akses berbeda, karena itu peneliti membuat dan menghasilkan alur flow menjadi bercabang untuk kedua user berbeda. Role HRD dapat melakukan action persetujuan untuk approval klaim atau tidak dari klaim yang di ajukan oleh tiap-tiap karyawan. Dan Role Karyawan adalah untuk melakukan pengajuan klaim kesehatan dan cuti. 


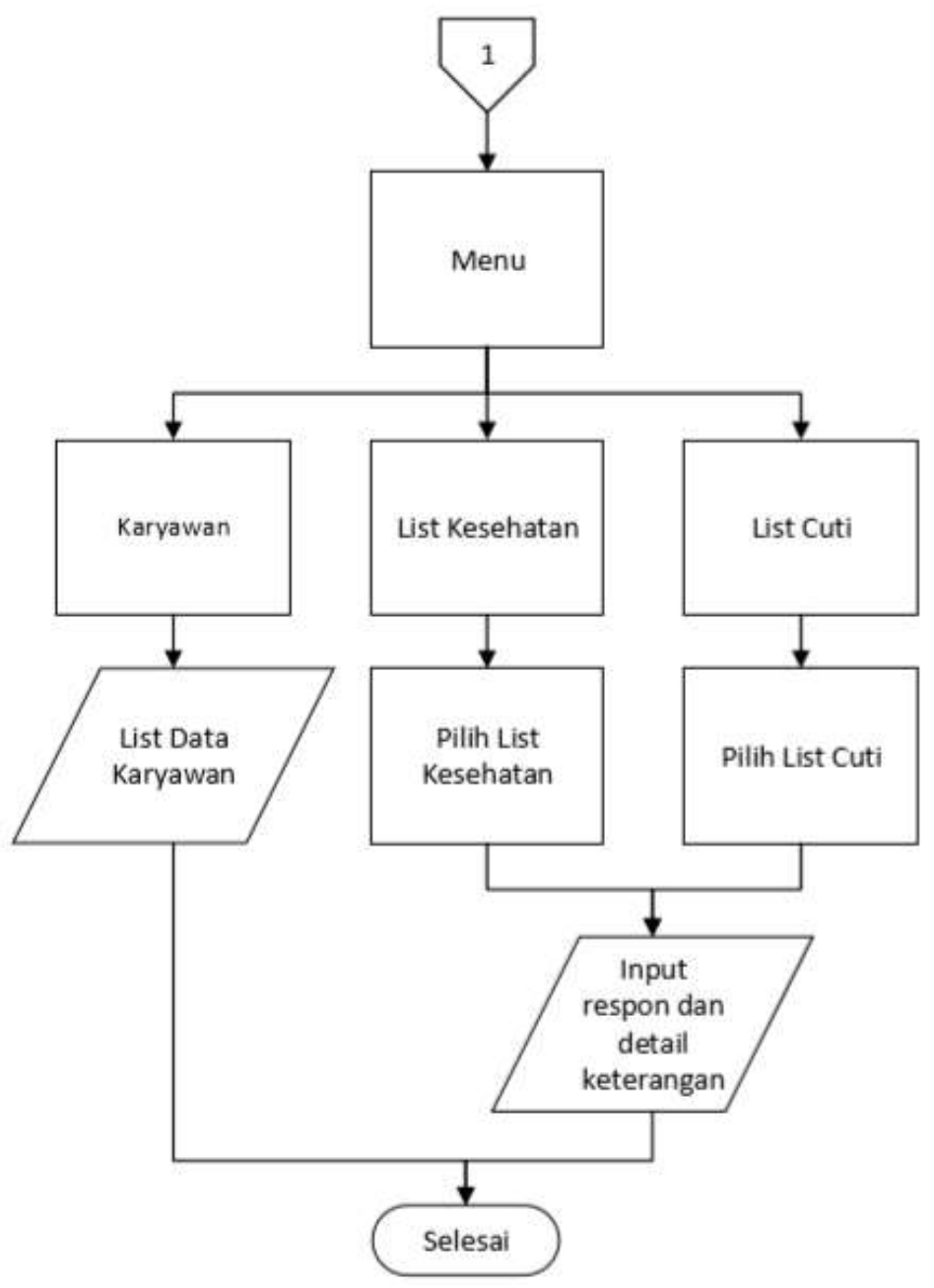

Gambar 3. Flowchart Role Menu

Aplikasi akan menampilkan menu utama awal untuk memilih menu apa yang akan dipilih. Jika user memilih menu karyawan, atau list kesehatan ataupun list cuti. Maka masing-masing menu disini memiliki fungsi berbeda dari hasil flowchart yang sudah peneliti buat maka menghasilkan rancangan tampilan seperti ini:

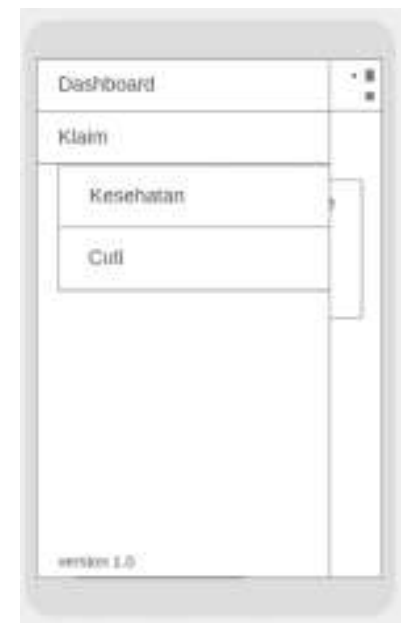

Gambar 4. Rancangan Tampilan Menu Utama

Berikut adalah tampilan rancangan yang dihasilkan dari flowchart proses berjalanan kemana menu menu tersebut ditentukan dalam setiap prosesnya. Tampilan rancangan ini memudahkan user untuk 
memilih dan membedakan fungsi masing - masing serta output yang akan keluar dari aksi yang dipilih saat dimenu utama. Dan dari hasil rancangan ini menghasilkan tampilan akhir untuk aplikasi seperti ini:

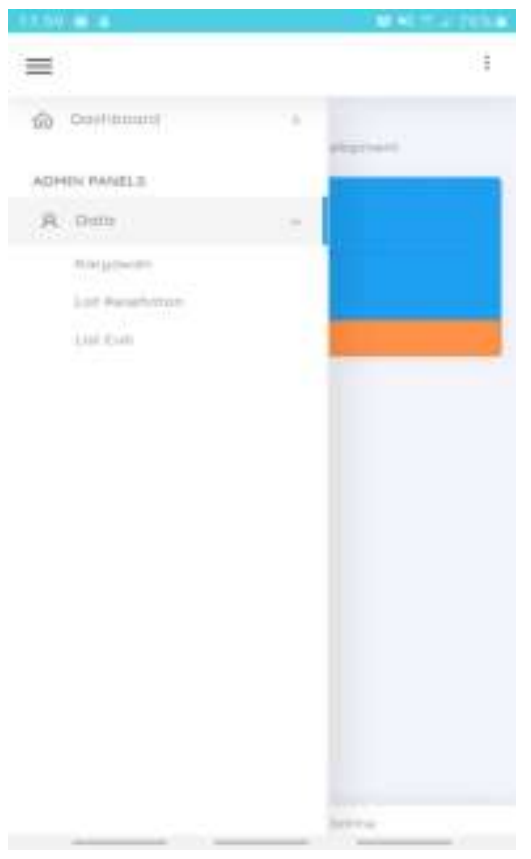

Gambar 5. Tampilan Menu Utama

Tampilan menu utama ini muncul diawal user memilih button burger list di pojok kiri atas, setelah itu akan tampil side menu yang menghasilkan list menu yang sudah disediakan sesuai role user saat itu. Dengan tampilan ini user bisa mengerti bahwa akses mereka hanya terbatas pada tampilan menu yang tampil pada side menu aplikasi. Berikut adalah data yang ditampilkan dari hasil luaran informasi :

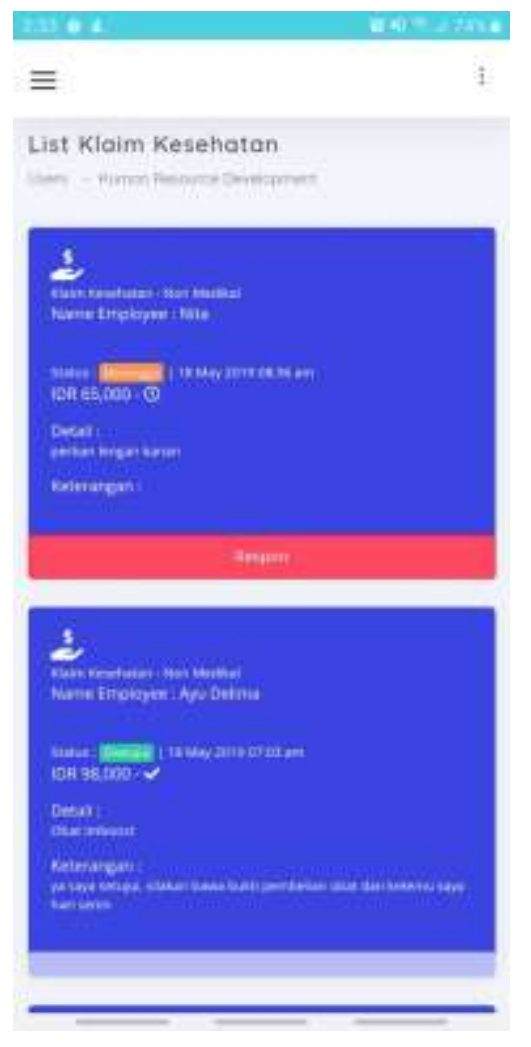

Gambar 6. Tampilan output data klaim kesehatan 


\section{SIMPULAN}

Dengan dibuatnya aplikasi klaim berbasis android ini diharapakan setiap karyawan dan proses klaim pada PT Protonema dapat lebih efisien dan efektif. Dan mengurangi penggunaan kertas, serta menekan cost pembelian kertas. Aplikasi klaim pada PT Protonema sangat membantu dalam memberikan kemudahan dalam melakukan klaim kesehatan dan pengajuan cuti. Aplikasi sistem klaim pada PT Protonema menggunakan database sehingga duplikasi data dan kesalahan input dapat diminimalisir. Aplikasi sistem klaim pada PT Protonema sangat membantu untuk mempersingkat waktu dalam pengajuan klaim dan cuti.

\section{DAFTAR PUSTAKA}

Cucus, A. (2015). PERANCANGAN SISTEM INFORMASI KLAIM ASURANSI JIWA MENGGUNAKAN Ms.VISUAL BASIC 6.0. PADA PT. ASURANSI JIWASRAYA KOTA BANDAR LAMPUNG. Jurnal Sistem Informasi Dan Telematika, 2, 32-25.

Harahap, Nazarudin Safaat. (2015). Pemprograman Aplikasi Mobile Smartphone dan Tablet PC Berbasis Android. Kusumah, P. (2014). Perancangan Olahraga Pendidikan untuk sekolah - sekolah. Jurnal Olahraga Pendidikan, 1, 2. Mardiani, S. \& E. (2018). Aplikasi Penjualan Dengan Visual Basic, Xampp \& Data Report.

Utomo, Dwi Prasetyo, Andrei Ramani, Y. A. (2015). Perancangan Sistem Informasi Klaim Persalinan Studi Kasus di Badan Penyelenggara Jaminan Sosial KesehatanKantor Cabang Jember. Sistem Informasi, 2. 